\title{
How Do High School Students Perceive the Entrepreneurial Education
}

\author{
Sorina Ioana MISU \\ The Bucharest University of Economic Studies, Bucharest, Romania \\ misu.sorina.ioana@gmail.com
}

PICBE | 945

\begin{abstract}
Entrepreneurial education is the new must of today's young generations. Either the teenagers or the young adults envision a career in IT\&C, medicine, law or architecture, nowadays society requires from them to possess knowledge about how a business works or how it can be successfully developed. This brings up the question for curricula developers when should be introduced business education to children. For the time being, in Romania as well as in most of the European countries, they make acquaintance with the entrepreneurial education during high school. The present study wants to throw a glimpse at how pupils themselves perceive the study of entrepreneurial education and how effective is for their future to start learning about entrepreneurship concepts around the age of 16. Consequently, with the help of a quantitative research materialized in a questionnaire, the study has the objective to determine the perception of high school students in Romania about the entrepreneurial education and to evaluate its impact in a number of different matters. They have been focused primarily on the decision of their future careers and the role the teacher plays in this process. The contributions of this study could be of high importance for both curricula developers that must take into account students and market's needs, as well as for the universities which offer business administration study programs. For the case of the universities, in order to develop coherent study programs, they need to be aware of the students' basic level of knowledge regarding entrepreneurship and their understanding gained through the mandatory subject of Entrepreneurial Education during the high school time.
\end{abstract}

Keywords: entrepreneurship education, high school students, career orientation, teacher support, formal education, non-formal education, leadership.

\section{Introduction}

Entrepreneurship as a force of economic development has for the last three decades captured the imagination of governments, industries and individuals (Van Praag \& Versloot, 2007). This acknowledgment has led to a sharp increase in the number of entrepreneurship education programs, however, there is little research on the effectiveness of them (Huber, Sloof, Van Praag, 2014).

Researchers within the field of entrepreneurship education have mainly focused on students at the tertiary level (Rosendahl-Huber et al., 2012) and there is little evidence about its effectiveness at secondary level. One of the effects of academic entrepreneurship is the technology transfer via licensing agreements (Dima, AM., et al., 2017). However, most of the studies focus on how entrepreneurship education generally impacts the economy (e.g. Ogbari et all., 2018; Luca et all., 2013; Koe et all., 2012), how teachers can influence the spirit of entrepreneurship development (Teerijoki, Murdock, 2014; Moberg, 2014), but evidences regarding the perception of the pupils themselves are almost inexistent. We have learned about how entrepreneurial skills increase the students' capacity of thinking critically (Bejinaru, R., 2018). However, it has been more handy and common to investigate regarding 
the perception and impact among students at tertiary level (Marinescu, Botea, 2017; Ambad, Damit, 2016; Kuttim et all, 2016) as undergraduate and graduate student are the closest to the labor market and to the moment when they have to take a final decision regarding their career.

This paper's intention is to switch the point of focus to the pupils themselves given the circumstances that during the inferior high school level happens their first meeting with the entrepreneurial education. First impression matters so I considered as being essential to discover how pupils perceive knowledge and attitudes belonging to the entrepreneurial field.

Hence, this research paper's aim is to determine the perceptions of high school students regarding the study of entrepreneurial education. Since the study has been conducted in Bucharest, Romania and the answers have been given by students in Bucharest, Romania, the later on discussed results might illustrate better a reality that belongs to the Romanian space and be of more significance to the Romanian universities and curricula developers. However, Romanian is a country that belongs now for more than twelve years to the European Union. Moreover, given the fact we all live in a digitalized society where teenagers have access to information from all over the world in a matter of seconds, it is not forced to assume that the results obtained in this study could characterize teenagers from many countries and could give useful hints for stakeholders that aren't necessarily belonging to the Romanian space. The trends show us that the specificity related to the digitalization process is the dynamic rhythm and the new perspectives (Dima, MA., Vasilache, S., 2016).

It was assumed from the beginning there are a number of factors that have the ability to influence the perceptions of the high school students regarding the entrepreneurial education. Setting as a departure point the main question of the research the study had as objective to determine the perception of the high school students in four different and specific areas:

(a) career orientation

(b) formal and non-formal methods of education

(c) leadership

(d) teachers' performance

Hypotheses

For a better understanding of the research's issues, there have been formulated a number of four hypotheses, so that the study could offer a consistent and complex image of the teenagers' perceptions regarding the entrepreneurial education.

The first research hypothesis of the study (H1) states that the study of entrepreneurial education helps high school students to orient in their future career.

The second research hypothesis of the study (H2) states that entrepreneurial education is gained through both formal and non-formal methods of instruction.

The third research hypothesis of the study (H3) states that the study of entrepreneurial education develops in high school students leadership skills.

The fourth research hypothesis of the study (H4) states that the entrepreneurial education teacher has the ability to influence the students' decision to follow a career as entrepreneurs. 


\section{Literature review}

In this part of the article, research on career orientation, formal and non-formal methods of investigation, leadership and teachers' performance, all within the field of entrepreneurial education at high school level, will be briefly summarized.

\section{Career orientation}

The central purpose of education is to form and to develop in a conscious, systematic and organized way the individual's personality with the goal to integrate him through efficient methods in the social life (Soare, 2008, p.7). One of the most important aspects of the adult's social life is his professional life and an early facilitation of the career orientation process done in schools could end up in excellent results regarding the match between abilities and job descriptions.

However, the choice of an entrepreneurial career becomes a challenging aspect in a society where for five consecutive decades the idea of entrepreneurship did not exist as it was structured according to the rules of the planned economy. Entrepreneurial education has been introduced in the Romanian high schools in 2003 and since then all study profiles have included in their core curricula one hour per week of entrepreneurial education destined to $10^{\text {th }}$ grade students.

Nevertheless, so far, it has not been measured in any study the impact the introduction of this subject had for the generations of Romanian young people. Neither if its core competencies are efficient for the youngsters' career development, nor if the number of Romanian entrepreneurs has increased since the introduction of this subject (Rusu, 2015, p. 15)

Generally speaking, at European level, studies have shown ("Entrepreneurship in the EU and beyond" - Flash Eurobarometer no. 354 in Rusu, 2012, p. 45-47) that most European individuals prefer being employed rather than opening their own businesses. This is why entrepreneurship is one of the key focuses at European level and it constantly provides a source of preoccupation when it comes to development and cohesion strategies. The European Commission states that the entrepreneurship represents an individual's ability to turn ideas into actions. Moreover, it requires a set of key features such as spirit of innovation, creativity, risk taking and the ability to plan and manage projects in order to achieve objectives. Moreover, Europe's welfare and economic growth depends on its capacity to sustain the development of entrepreneurship. It creates first of all new jobs, opens new markets as it represents through the SMEs the main source of employment in the European Union. This is why it has been developed The Entrepreneurship 2020 Action Plan which identifies three area where immediate interventions must be done. Hence, the first step to be made is to take care of the entrepreneurial education in order to ease the business creation. Secondly, it is needed a reduction of administrative barriers and thirdly, bringing back to life the culture of the entrepreneurship.

In this context, it is essential to be developed a positive attitude regarding entrepreneurship in order to boost young people's intention to follow an entrepreneurial career.

Formal and non-formal methods of entrepreneurial education

Formal education represents the sum of systematic and intentional influences designed within a specialized institution (i.e. school, university) with the purpose of creating the 
human personality (Cucos, 2002, p.45). This type of education has as purpose the assimilation of organized knowledge and the development of key competences necessary for the individual to function within the society (Rusu, 2015, p. 15).

Non-formal education regards the sum of activities that influence the educational process and happen outside the classroom or through optional activities (Cucos, 2002, p.45). Hence, the non-formal education does have a formative character, but the activities developed are flexible and meet the specific interests of the individuals (Rusu, 2015, p.15).

There is an on-going dispute regarding what should prevail in teaching entrepreneurial education. Formal education cannot cover the totality of learning needs and non-formal education methods come as a natural fill in. Non-formal educational methods take out from the educational process the teaching function giving place to the learning function. They are however effective only if they correlated and coordinated with the formal education methods (Derlogea \& Bota, 2011).

In terms of entrepreneurial education, while entrepreneurship courses will continue to be the most important source of knowledge, competence and motivation on entrepreneurial processes, skills and know-how, curiosity-triggering entrepreneurial education as embedded in the existing education structures will be important in extending entrepreneurship coverage (Teerijoki, Murdock, 2014).

Leadership

R.B. Reich (Reich, 1987) supported the idea that global competitiveness in today's society is maintained if collective entrepreneurship is promoted. In this way, the collective effort will be greater than the sum of individual contributions and entrepreneurial teams should enjoy a greater respect than individual leaders and geniuses.

However, entrepreneurs play an important role in bringing in economic changes and advancements to a country's economy (Koe et all., 2012). This is a role of major importance someone assumes and individuals that decide to open a business must first of all possess the capacity to identify opportunities, the desire to take risks, an unconventional way of thinking and recycling existing ideas, the need to be the best, the need to succeed, the awareness of its own strong and weak points, the ability to work within an uncertain environment (Pattison, 2006). So, before stepping in into the business and assume a further managerial role, an individual must demonstrate leadership assets. Later on, management and business administration skills will come to complete the needs of a successful entrepreneur (Ciolan, 2003).

This is why, when meeting for the first time the entrepreneurial education, $10^{\text {th }}$ grade high school students should be made aware of this duality imposed by the entrepreneurial choice. Teachers on their side, should try to best cover this necessity and expose pupils to the entrepreneurial way of thinking that embeds both the leadership and the managerial needs. Entrepreneurship is beyond the personal attitudes, it's a specific process that leads to welfare and individual well-being (Rusu, 2015). Entrepreneurs are made, not born (Krueger, 2007). Teachers' performance

Entrepreneurial education teachers should not give their students the answers, but help them identify the right questions. Entrepreneurship is not necessarily about starting a business, it is a way of thinking itself, this is why through the entrepreneurial education there 
should be developed, with the help of teachers, attitudes, be given information and competencies that later on would lead to entrepreneurial behaviors (Rusu, 2015).

Even though entrepreneurship itself is one of the most intense studied phenomena currently, as well as the entrepreneurial education and its subsequent implications, the role of the teacher as key stakeholder in the process of embedding entrepreneurial thinking and attitude has not been systematically investigated. Furthermore, the teacher's attitudes, commitment and actions towards implementing complementary teaching goals, as well as how these attitudes can be formed has received only little attention (Teerijoki, Murdock, 2014). Furthermore, the connection between teaching beliefs and activities has been widely explored and has demonstrated positive results (see e.g. Muma, Martin, Shelley, Holmes, 2010; Northcote, 2009; Vaino, Holbrook, Rannikmae, 2013). This connection however, has not yet been explored in relation to entrepreneurship education and teaching (Teerijoki, Murdock, 2014).

Literature suggests (Soare, 2008, p. 16) that a new model of teacher should develop, meaning the entrepreneur-teacher. This teacher would approach the educational process and the subsequent activities from the perspective of innovation, action and cooperation. He would be the person that would involve itself in the extended scholar life of pupils and it would face challenges through developing projects of educational development.

Additionally, the same author suggests the entrepreneur teacher is the one that disregarding the subjects he teaches, is the one that presents to the pupils the opportunity to become their own employers. They would encourage creativity and would develop an environment where taking risks would be safe and the entrepreneurial personality could thrive in teenagers.

\section{Methodology}

This section is designed to present the steps taken in order to put together the present research paper for the purpose of answering the research question of this study.

This research was designed to examine the perceptions of high school students regarding the study of entrepreneurial education.

In order to answer the research question it has been used a quantitative approach for developing the data collection. For this purpose it has been used the investigation method developed through an online survey. The 19 question survey was designed and distributed through Google Forms platform. It has been disseminated through randomly selected high school students groups and a total of 269 people have anonymously answered the survey.

Sample description.

In order to get some knowledge regarding the perceptions of the high school students regarding their opinions in the matter of studying entrepreneurial education, the 269 obtained answers have been analyzed.

The 269 answers were obtained from students that learn in a high school from Bucharest, Romania. $63.2 \%$ of the respondents were at the moment of the study in the $10^{\text {th }}$ grade (around the age of $16-17$ years old) and the rest of $36.8 \%$ were at that moment in the $11^{\text {th }}$ grade (around the age of 17 - 18 years old). Furthermore, in terms of gender, $60.2 \%$ of the survey's participants were boys and $39.8 \%$ were girls. In terms of field of studies, $45 \%$ of the 
respondent students follow a degree in philology and social sciences, whereas the rest of $55 \%$ of the students follow a degree in exact sciences.

A first observation to the sample leads us to the conclusion that the analyzed opinions belong mostly to students that have been studying entrepreneurial education only for one semester at the moment of the survey. Additionally the majority of the respondents belong to the male gender and follow a degree in exact sciences. These sample characteristics will be taken into account when drawing conclusions especially at questions that aim the choice of the entrepreneurial field, the advantages and disadvantages of the entrepreneurial life and the possible moment of starting a career as a business man.

Besides of the sample characteristics, at the interpretation of the results it also has to be taken into account the fact that the educational content of any subject is interpreted differently by the pupils. They each have their own backgrounds and personal characteristics that influence the type of effects educational approaches have on them (Ames, 1992; Maehr, 1994). Additionally to this, the sample is entirely formed of teenagers, a time of life when people experience one of the most complex changes physically and cognitively.

Survey description

At this research study it has been obtained 269 answers from high school students that all study in one institution of Bucharest, Romania. The data has been collected in February 2019 and each of the student has answered benevolently at the questions.

The designed instrument for collecting the data of this study consists of five sections.

The first section was designed to gather identification information of the respondents.

The next four sections have each comprised questions especially designed to obtain data for the purpose of each of the set hypotheses. However, the questions have been imagined in such a way that the respondent would find a logical sequence between them and that the answering of one question could facilitate the process of answering for the next one.

\section{Results and discussions}

This section of the research paper focuses on delivering an interpretation on the results that have been obtained after analyzing the answers received through the survey. It is of great importance to interpret the results in the context of the actual scientifically knowledge available so that they can help other researchers and different other stakeholders of the topic to better understand the issues and to further develop it.

The first hypothesis explores whether the study of entrepreneurial education helps high school students to orient in their future career.

The questions designed to explore this hypothesis aimed to find out whether the study of entrepreneurial education helped the pupils to add the possibility of becoming entrepreneurs to their future career options list.

At the survey, two categories of respondents took part, $10^{\text {th }}$ graders which at the moment of the survey have just completed one semester of entrepreneurial education and $11^{\text {th }}$ graders that at the moment of the survey have finished their one year of entrepreneurial education studies. I wanted to explore what was their opinion regarding the entrepreneurial career by the end of the $9^{\text {th }}$ grade (i.e. just before the moment they began studying entrepreneurial education) and by the moment at which the survey happened (i.e. after having studied entrepreneurial education). By the end of the $9^{\text {th }}$ grade, $29.7 \%$ of the pupils 
have started to take into account this possibility, whereas by the moment of the survey, the figure has increased to $36.8 \%$ of the surveyed pupils. Also the figures regarding their high and very high intention to follow the entrepreneurship path had an ascending trend from before the study of entrepreneurial education to after the study of this subject. $10 \%$ of the high school students had a high intention to open a business and $8.6 \%$ a very high intention to become entrepreneurs even before the study of this subject in school. After the study of the subject, the figures increased to $17.8 \%$, respectively $14.1 \%$.
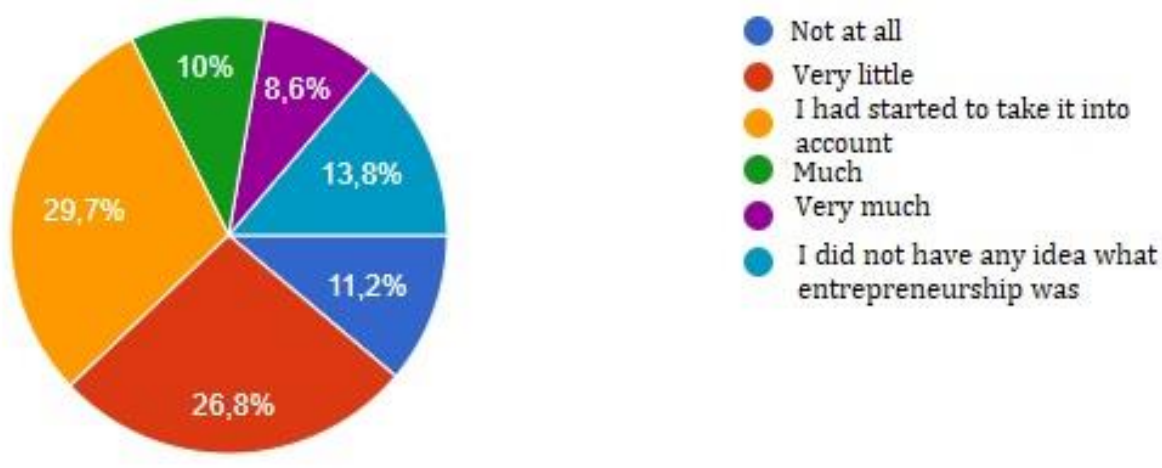

Figure 1. How attractive the possibility to choose the entrepreneurship path seemed by the end of the $9^{\text {th }}$ grade entrepreneurship was

What it is a positive aspect is the fact that if by the end of the $9^{\text {th }}$ grade $13.8 \%$ of the pupils did not have any idea what a career in entrepreneurship stands for, after having studies the subject in school only $1.9 \%$ still remained clueless.

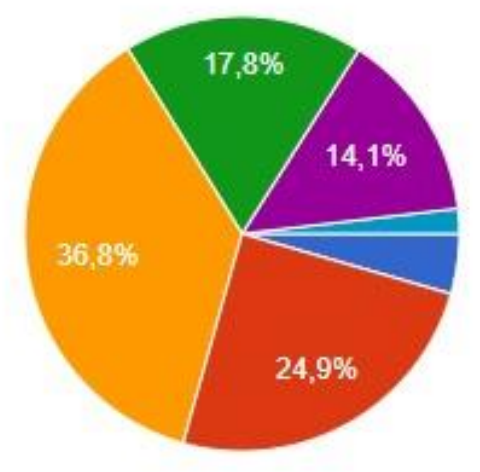

Source: Author's own results

Figure 2. How attractive the possibility to choose the entrepreneurship path seems after having studied entrepreneurial education

Source: Author's own results

Moreover, another question designed to explore the first hypothesis, asked students to choose what they considered to be the advantages of the entrepreneurial career. On the 
other side, pupils have also been asked to choose what they considered to be the disadvantages of the entrepreneurial life. Generally speaking, top 3 answers of students for why they would choose to become an entrepreneur are the freedom to be their own boss (chosen by $79.2 \%$ of them), financial comfort (chosen by 58\% of them) and a flexible working schedule (chosen by $52 \%$ of them). At the other hand, in terms of disadvantages of the entrepreneurial career as seen by a high school student, the main disadvantage chosen by $71.4 \%$ of the respondents would be the stressing lifestyle generated by too many responsibilities, secondly, the incertitude caused by the lack of a constant revenue, chosen by $63.6 \%$ of the respondents and at far away distance, on the third place, the concern of constantly looking for business partners, chosen by $36.8 \%$.

One last question that was designed to feature to what extend high school pupils are drawn to the idea of entrepreneurship has asked them to choose hypothetically the field in which they would open a business. Table 1 shows their top preferences.

Table 1. Field in which pupils would open a business

\begin{tabular}{|l|c|}
\hline Field of business & $\begin{array}{l}\text { The percentage in which it has been } \\
\text { chosen }\end{array}$ \\
\hline 1. IT\&C & $24.9 \%$ \\
\hline 2. Tourism and hospitality services & $16.7 \%$ \\
\hline 3. Wellness \& beauty & $15.2 \%$ \\
\hline 4. Online store & $14.1 \%$ \\
\hline Male's preferences & $36 \%$ \\
\hline 1. IT\&C & $17.5 \%$ \\
\hline 2. Online store & $15 \%$ \\
\hline 3. Tourism and hospitality services & $8.7 \%$ \\
\hline 4. Constructions & \\
\hline Female's preferences & $28 \%$ \\
\hline 1. Wellness \& beauty & $19.6 \%$ \\
\hline 2. Tourism and hospitality services & $11.2 \%$ \\
\hline 3. Online store & $10.2 \%$ \\
\hline 4. Events organization & Source: Author's own results
\end{tabular}

It can be noticed from table 1 that the general preference for a field in which a business would be opened is the IT\&C sector, however, this seems to be a preference exclusively of male students, as for the female pupils it only comes fifth in their choices with $8.4 \%$ of the girls having chosen this field. Tourism and hospitality services, where it has been included the managing of bars, cafes and restaurant has been equally preferred by both girls and boys, as well as the possibility to open an online store. A major difference in males and females options is the choice to open a business in the field of wellness and beauty, section that included spas, gyms and beauty salons. This was the number one option of the female respondents whereas it doesn't appear in the male's top five. 
In conclusion, it can be stated that the first hypothesis has been confirmed and the study of entrepreneurial education does help high school students orient into their future career. Moreover, the study of this subject helps students to better understand entrepreneurship and helps them realize how they can explore this possibility and what opening a business implies.

The second hypothesis explores whether the entrepreneurial education is gained through both formal and non-formal methods of instruction. Students have been asked to mark two affirmations with their level of agreement. This has been designed in order to determine their perception regarding the formal and non-formal types of education, when it comes to entrepreneurship. Figures 3 and 4 show the results of their options.
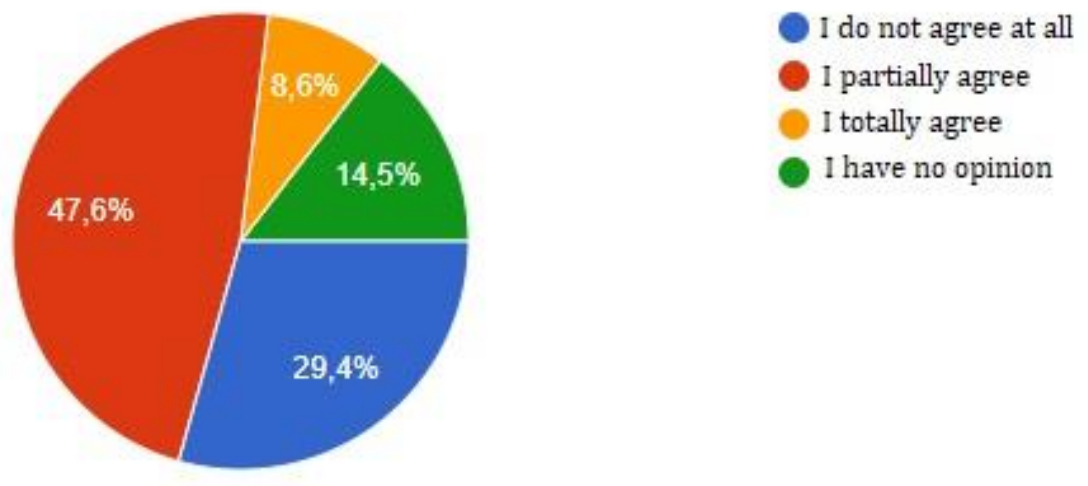

Figure 3. Answers to question "An entrepreneur is born and not made"

Source: Author's own results
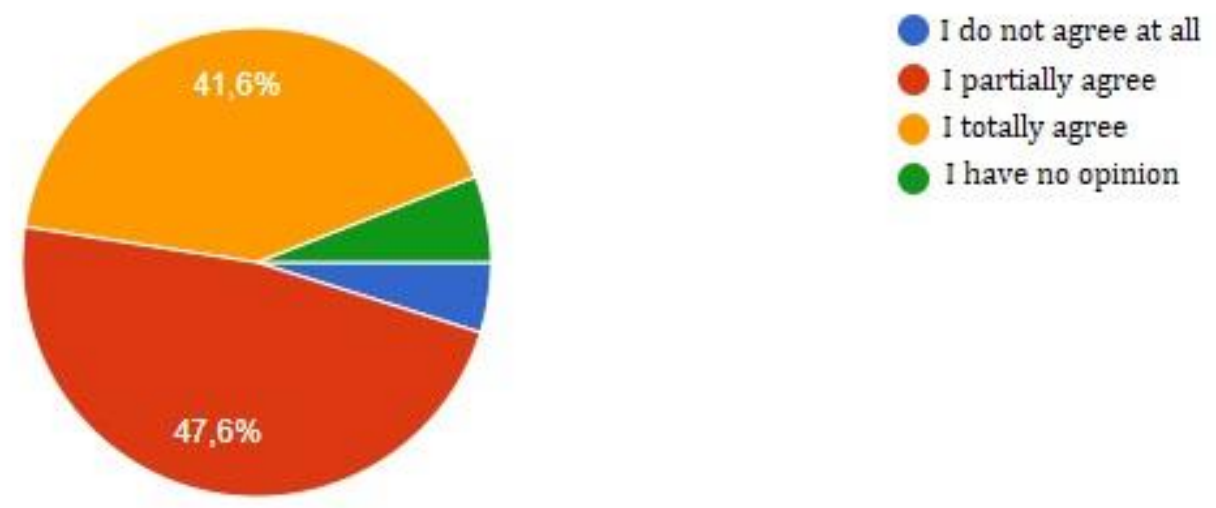

Figure 4. Answers to question "A good entrepreneur is made after a lot of studying"

Source: Author's own results

As it can be seen in the above figures, the conclusion that can be drawn is that pupils realize that in order to become a successful entrepreneur, native skills are not enough, they 
need to be educated, polished, developed and perfected through a great deal of studying. Pupils' perception match researches that have been performed (Boulton and Turner, 2005; Mellor et al., 2009) that show the fact that entrepreneurship can be taught to people.

Additionally, pupils have been asked whether stories of successful businesses drive them to opening their personal ones. More than $40 \%$ of the respondents said that stories represent a high source of inspiration and 30\% said they find them in a very high or even their main source of inspiration when thinking to become entrepreneurs. The tendency shown by these answers states that pupils also find alternative sources of studying entrepreneurship and these are from the lessons of great and successful business men.

Another question designed to explore pupils' perception regarding methods of formal and non-formal entrepreneurial education was when they have been asked to indicate the most trustful sources of information regarding entrepreneurship. Table 2 shows the respondents' answers.

Table 2. Most trusted sources of information regarding entrepreneurial education

\begin{tabular}{|l|c|}
\hline \multicolumn{1}{|c|}{ Sources of information } & Percentage of respondents \\
\hline $\begin{array}{l}\text { Lectures of business administration } \\
\text { faculties }\end{array}$ & $55.4 \%$ \\
\hline $\begin{array}{l}\text { Classes of entrepreneurial education in high } \\
\text { school }\end{array}$ & $50.9 \%$ \\
\hline Trainings offered by certified trainers & $48.3 \%$ \\
\hline Stories of successful businesses & $37.5 \%$ \\
\hline Business and leadership books & $32.3 \%$ \\
\hline
\end{tabular}

The figures shown in table 2 indicate the fact that formal education methods enjoy a great deal of trust among high school students. These are in the top of their choices regarding the sources of information to educate themselves in terms of entrepreneurship. It is however of worth to observe the fact that business and leadership books come only fifth in the top of their preferences. As formal education in high schools and universities comprise in a high amount self-study from books, it pops up the question why pupils trust so much classes and lectures, but not books. An assumption could be the fact that pupils from lower secondary level still have the expectation and the need that someone else, in this case the teacher, to organize the study process and the pupil's/student's duty remain only to pay attention at what the teacher explains.

Exploring more the field of formal and non-formal education, students have been asked to opinionate regarding the best age when entrepreneurial education should be introduced to the curricula. The majority, i.e. $27.5 \%$, answered that it should be introduced in the first year of high school, meaning around the age of 14-15 years old. The second preferred answered indicated the actual state of being, meaning the $10^{\text {th }}$ grade and their third preferred option was the $8^{\text {th }}$ grade which indicated the age of 13-14 years old.

These answers indicate that pupils perceive the first half of teenage years as the most suitable time of discovering and understanding entrepreneurship as this is the moment when the majority of them start to shape their career ideals. An earlier introduction would be too 
far away to the moment when they would actually start working and would be at an age level the dream job is most commonly associated with the standard professions such as doctor, teacher, lawyer, policemen (Csikszentmihalyi \& Larson, 1984). A later introduction of the study of entrepreneurial education than $10^{\text {th }}$ grade would be too close to the moment of their final decision and there would be the chance little amount of people to seriously take it into account.

PICBE | 955

Last but not least, in the section exploring the second hypothesis, one last question has been asked, which would be the most suitable moment to open a business. The purpose of this question was to determine the pupils' perception about how developed ones education and formation should be before starting a career as an entrepreneur. More than half of the respondents (i.e. 53.5\%) considered that a business should be started after completing business administration studies. Second preferred answered by the pupils is between the age of 24 - 29 years old. The ratio of preferences keeps constant also on the analysis malesfemales. These figures indicate the fact that high school students consider that one should not open a business until it is not fully trained in this matter and that formal education counts to a great extent to the successful start of a business.

In conclusion it can be stated that the second hypothesis is confirmed as well and that high school students are aware of the fact that entrepreneurial education is gained through both formal and non-formal methods of education. However, the previously analyzed answers indicate a higher perception regarding the importance of the formal education methods.

The third hypothesis explores whether the study of entrepreneurial education develops in high school students leadership skills.

An entrepreneur is first of all a manager, for himself and for his employees as well. He needs to deal with everyday situations, find solutions, get them solved, meet business partners, meet clients and so on and so forth. However, for the long lasting success of a business this is not enough. The entrepreneur should also be taught to motivate, to inspire, to be creative, to think outside of the box, to be a leader, for himself as for his employees. In a Danish study (Moberg, 2014) it is made the difference between two types of education, through and for entrepreneurship. Education for entrepreneurship focuses on the cognitive entrepreneurial skills and on the content, whereas the education through entrepreneurship focuses on promoting non-cognitive entrepreneurial skills and has a more pedagogical orientation. It is thought that the second type of education develops better the leadership skills of a student. Generally speaking, the Romanian pre-university teaching methods are known for their great focus on the cognitive skills development and $10^{\text {th }}$ grade entrepreneurial education does not make an exception. Under these circumstances, the third hypothesis has been investigated and pupils' perception with the help of the following questions.

The first intention was to determine the perception of the students regarding the connection between entrepreneurship and leadership. 58.4\% of them believe that a good entrepreneur is in high amount a good leader as well. 19.3\% think that a good entrepreneur is in totality a good leader as well and only $4.1 \%$ think that a good entrepreneur should not be a leader as well. 
Figures 5 and 6 illustrate how pupils perceive the development of their leadership skills through entrepreneurial education and whether the activities proposed at this subject made them practice the skills. The results do not show a consistent pattern regarding the development and practice of leadership skills through the study of entrepreneurial education. The answers regarding the development of leadership skills show that pupils perceive this situation as happening at a very low rate. On the other hand, when asked about the hypostasis to practice leadership skills the respondents indicated they've been put almost equally to practice them both in a high and small degree. The conclusion that can be drawn is that given the circumstances that in the Romanian high school teaching system education is mostly done for entrepreneurship (Moberg, 2014) it is not uncommon to observe a lack of development and practice of leadership skills.

In conclusion, it can be stated that hypothesis number three was not confirmed and that pupils perceive the status quo of this situation. They receive content information regarding entrepreneurship and accumulate the necessary knowledge to understand the field of business, but there is still plenty of room to develop in themselves leadership skills.

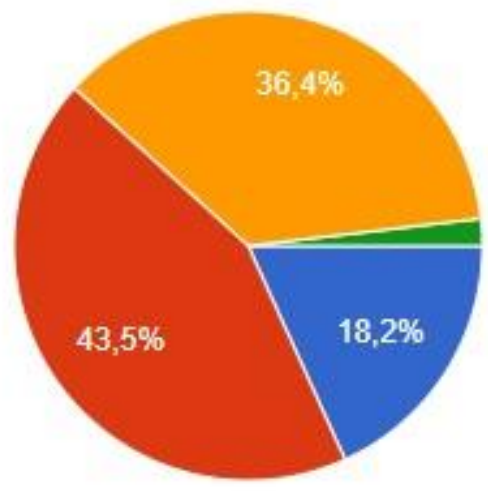

Not at all

In small degree

In high degree

Totally

\section{Figure 4. The degree in which leadership skills are developed by the study of entrepreneurial education}

Source: Author's own results

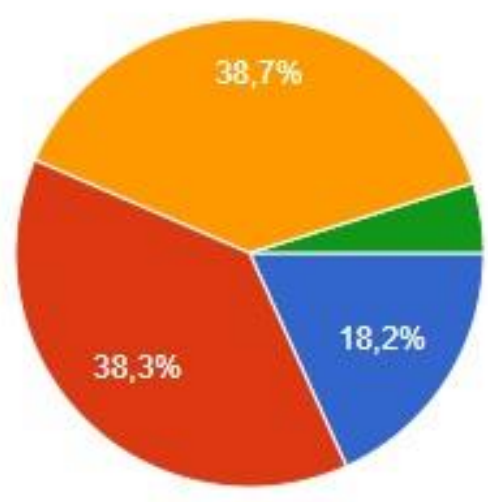

Not at all

In small degree

In high degree

Totally 


\section{Figure 5. The degree in which leadership skills are practiced through the study of}

entrepreneurial education

Source: Author's own results

The fourth hypothesis explores whether the entrepreneurial education teacher has the ability to influence the students' decision to follow a career as entrepreneurs.

Studies show that the teacher is the key stakeholder in the process of embedding entrepreneurial thinking and attitude and that the teacher's attitudes, commitment and actions may have the power to influence pupils (Teerijoki \& Murdock, 2014). Given these circumstances, the following questions respondents needed to answer, will offer their perception regarding the role of the teacher in the decision to follow an entrepreneurial career.

Table 3 shows the pupils' perception regarding the qualities a good entrepreneurial teacher should possess. Pupils assume that first of all, a good entrepreneurial teacher should have business experience. The next set of qualities belong to the area of general qualities that a teacher should have, i.e. persuasion skills, assertiveness skills and charisma.

Table 3. The qualities of the entrepreneurial education teacher

\begin{tabular}{|l|c|}
\hline \multicolumn{1}{|c|}{ Quality } & Percentage of respondents \\
\hline Business experience & $70.3 \%$ \\
\hline Persuasion skills & $62.5 \%$ \\
\hline Assertiveness skills & $59.9 \%$ \\
\hline Charisma & $50.6 \%$ \\
\hline Seriousness & $41.3 \%$ \\
\hline
\end{tabular}

Another intention regarding the exploration of the forth hypothesis was to analyze whether pupils perceive differently the teacher of entrepreneurial education in respect with the teachers of other subjects. Hence, they have been asked to name the aspects in which an entrepreneurial teacher should be different from the other teachers. Table 4 shows the results.

Table 4. The aspects in which an entrepreneurial education teacher should be different of other subjects' teachers

\begin{tabular}{|l|c|}
\hline \multicolumn{1}{|c|}{ Aspects of differentiation } & Percentage \\
\hline $\begin{array}{l}\text { Being connected to what happens in the } \\
\text { business and social environment }\end{array}$ & $78.4 \%$ \\
\hline $\begin{array}{l}\text { A thorough understanding of the business } \\
\text { environment }\end{array}$ & $49.1 \%$ \\
\hline Attitude in front of the pupils & $43.1 \%$ \\
\hline IT\&C knowledge & $35.3 \%$ \\
\hline Use of language & $28.3 \%$ \\
\hline
\end{tabular}


It can be observed from the above figures of table 4 that pupils perceive the entrepreneurial education teacher as a teacher of modern days who is permanently connected to events from the surrounding environment and that can have the capacity to explain those events to them.

Last but not least, pupils have been asked to rate whether the entrepreneurial education teacher has the capacity to influence their decision to follow a career in entrepreneurship. Figure 6 shows a biased perception of students as almost half of them (i.e. $46.8 \%$ ) believe that the teacher has this capacity in high degree, whereas the other half (i.e. $45 \%$ ) believes the teacher has a reduced capacity to influence on this matter. Given the fact that according to the respondents, among teachers' qualities should be the assertiveness and the persuasion skills, it can be assumed that there is a direct link between the amount in which this qualities are met in a teacher and the pupils' decision to take into account a career in entrepreneurship.

In conclusion, it can be stated that a teacher of entrepreneurial education could have the capacity to influence pupils' decision to orient themselves towards a career in entrepreneurship. Given the circumstances that the respondents were teenagers, the age when they look for models and if teachers meet the pupils' perceptions regarding the qualities of an ideal entrepreneurial teacher, then the high school student could pay enough attention to the lessons in order to get inspired towards the entrepreneurship path.
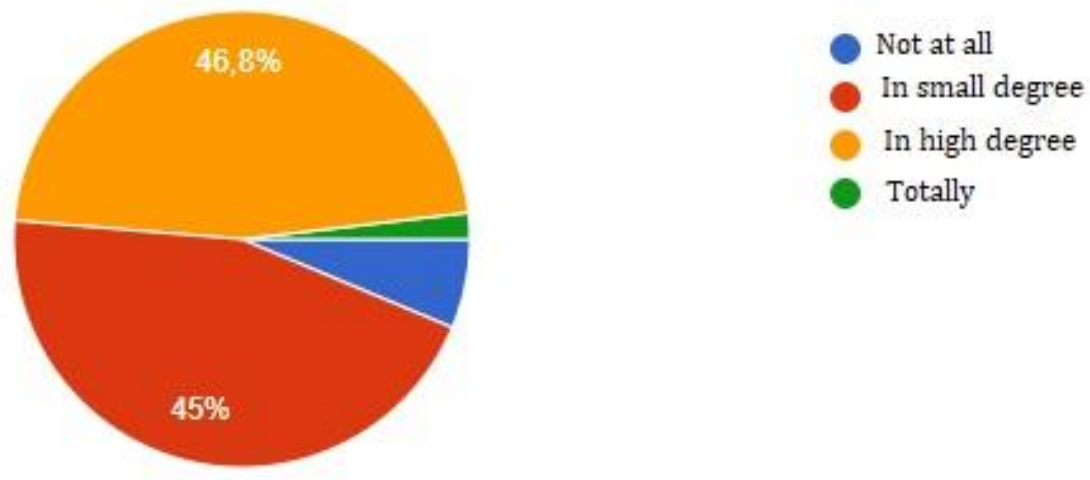

Figure 6. The capacity of the entrepreneurial teacher to influence pupils' career choice

Source: Author's own results

\section{Conclusion}

In this paper it was presented the perception of a sample of high school students from Bucharest, Romania regarding the study of entrepreneurial education. Their answers have shown that the study of this subject does help them to orient for their future careers. Whether this means they intend to open a business at some future point of their lives or they decide to follow the lectures of a business administration degree, high school entrepreneurial education provides teenagers with a consistent glimpse regarding entrepreneurship.

The second observation made under this study suggests the fact that high school students perceive formal education methods as more effective for their entrepreneurial skills 
development. However, they are aware of the non-formal methods importance as well, but given the circumstances that the Romanian teaching system is primarily one based on the development of cognitive skills, the results make sense.

The previous results lead naturally to the next observation made within this study, i.e. students do not perceive entrepreneurial education study as the main tool for their leadership skills development. Students are aware of the duality embedded by an PICBE | 959 entrepreneur, the hypostasis of manager and the one of leader, but in their majority they felt they lacked enough opportunities to gain proper leadership skills through the study of entrepreneurial education.

With respect to the role the teacher of entrepreneurial education plays within the decision of the pupil to pursue the entrepreneurial field, their perceptions have been mixed. Almost half of them agreed the teacher has the capacity to influence, whereas the other half did not believe in this capacity. This could lead to the conclusion that the teacher's personality, charisma and way of presenting information in order to draw the pupil's attention are of great importance for the shape of the students' decisions.

As previously mentioned, discoveries of this research paper might be of interest for two main categories of stakeholders, without excluding any other interested party. The first category envisioned is the curricula developers that should constantly and continuously aim to match curricula purposes to the society's purposes as a whole. Due to the fact that entrepreneurship besides of being a field of work is also characterized by being a state of mind, curricula developers should continue to investigate the impact the entrepreneurial education has for the generations of young people.

The second category of stakeholders are the universities that offer business administration study programs. They could be interested in the level of entrepreneurial education their students have after finishing high school and on the same measure, which is the students' attitude regarding entrepreneurship. Based on this sort of information they can develop study programs that meet the real necessities of students in terms of entrepreneurial education, so that they can graduate with the proper knowledge, market requires from them.

Any other categories of stakeholders are welcomed to study thoroughly this research and further develop on its premises. Students, parents, business professionals or fellow researchers might explore in greater details the impact of entrepreneurial education in the Romanian society and dig deeper the relationships set by any of this research's hypotheses.

It must be acknowledged the fact that this research has some major limitations and its discoveries cannot be given the rank of general truth. First of all, the surveyed sample of students is rather small (i.e. 269 pupils) and it does not cover a representative geographical area for the Romanian space (i.e. the study has been conducted only in one high school from Bucharest). There are great chances that a replication of this study on a bigger sample or in a different geographical area lead us to slightly different results and observations and a greater variety of perspectives regarding the study of entrepreneurial education at high school level.

Last but not least, the question that we all need to ask is how we can better listen to the students and their needs expressed through their perceptions and offer them the perfect mix of education that would make tomorrow society and better and happier place. 


\section{References}

Ames, C. (1992). Classrooms: goals, structures, and student motivation. Journal of Educational Psychology, 84, 261-271.

Bejinaru, R. (2018), “Assessing students' entrepreneurial skills needed in the knowledge economy", Management \& Marketing, Challenges for the Knowledge Society, Vol. 13, No. 3, pp. 1119-1132, DOI: 10.2478/mmcks-2018-0027.

Boulton, C. and Turner, P. (2005). Mastering Business in Asia: Entrepreneurship. Singapore: John Wiley and Sons.

Ciolan, L. (2003). Dincolo de discipline. Ghid pentru învăţarea integrată/cross-curriculară. Bucureşti: Humanitas Educaţional

Csikszentmihalyi, M., \& Larson, R. (1984). Being adolescent: Conflict and growth in the teenage years. Basic Books.

Cucoș, C. (2002). Pedagogie Ediția a II-a revăzută și adăugită. Iași: Editura Polirom

Derlogea, Ș., Bota, G. (2011). 160 de activități dinamice (jocuri) pentru Team-Building Educație noformală civică și antreprenorială. București: Editura CASA. Retrieved from:https://alili2001.files.wordpress.com/2014/12/160-de-

activitc3a4c692c3a5c2a3i-dinamicejocuri-pentr-u-team-building.pdf

Dima, M.A. and Vasilache, S. (2016), "Trends in the internationalization of European higher education in a convergence perspective", Management \& Marketing. Challenges for the Knowledge Society, Vol. 11, No. 2, pp. 449-457 DOI: 10.1515/mmcks2016-0008.

Dima, A., Hadad, S., Luchian, I., (2017), "Review on the dimensions of business-university alliances", Proceedings of the 11th International Conference on Business Excellence, pp. 64-73, DOI: $10.1515 /$ picbe-2017-0007.

Huber, L.R., Sloof, R., Van Praag, M. (2014). The effect of early entrepreneurship education: Evidence from a field experiment. European Economic Review, 72, 76-97

Koe, W.L., Sa'ari, J. R., Majid, I. A., Ismail, K. (2012). Determinants of Entrepreneurial Intention among Millennial Generation. Procedia - Social and Behavioral Sciences, 40, 197 - 208

Krueger, N.F. (2007). What Lies Beneath? The Experiential Essence of Entrepreneurial Thinking. Entrepreneurship Theory and Practice, 31 (1), p. 123-138

Maehr, M. L. (1984). Meaning and motivation: toward a theory of personal investment. In R. Ames, \& C. Ames (Eds.), Research on motivation in education: Vol.1. Student motivation (pp. 115e143). Academic Press

Mellor, R., Coulton, G., Chick, A. Bifulco, A., Mellor, N. and Fisher, A. (2009), Entrepreneurship for Everyone, London: SAGE Publications

Moberg, K. (2014). Two approaches to entrepreneurship education: The different effects of education for and through entrepreneurship at the lower secondary level. The International Journal of Management Education, 12, 512-528

Pattison, M. (2006). Outstanding Talent: an entrepreneurial approach to practice. Australian Occupational Therapy Journal, 53, p.166-172

Reich, R. B. (1987). Entrepreneurship reconsidered: The team as hero. Harvard Business Review, May/June

Rosendahl-Huber, L., Sloof, R., \& Van Praag, M. (2012). The effects of early entrepreneurship education: evidence from a randomized field experiment. Discussion Paper Series, IZA DP No. 6512 
Rusu, C.R. (2015). Perfecționarea educației antreprenoriale din România prin folosirea metodelor nonformale în ciclul inferior al liceului. Cluj Napoca. Retrieved from: https://econ.ubbcluj.ro/Scoala_Doctorala/rezumate/RUSU\%20Carmen\%20Ramona .pdf

Soare, E. (2008). Educatia antreprenoriala.Ultima provocare a scolii. Bucuresti: V. \& I. Integral

Teerijoki, H., Murdock, K. (2014). Assessing the role of the teacher in introducing entrepreneurial education in engineering and science courses. The International Journal of Management Education, 12, 479-489

The European Commission. (2013). Entrepreneurship 2020 action plan: reigniting the entrepreneurial spirit in Europe. Retrieved from: https://eur-lex.europa.eu/legalcontent/EN/TXT/?uri=CELEX:52012DC0795

Van Praag, C. M., \& Versloot, P. (2007). What is the value of entrepreneurship? A review of recent research. Small Business Economics, 29(4), 351-382 